\title{
Il Faut Savoir Compter
}

\section{Citation}

Darnton, Robert. 2004. Il faut savoir compter. French Historical Studies 27(4): 725-731.

\section{Published Version}

http://dx.doi.org/10.1215/00161071-27-4-725

\section{Permanent link}

http://nrs.harvard.edu/urn-3:HUL.InstRepos:3403041

\section{Terms of Use}

This article was downloaded from Harvard University's DASH repository, and is made available under the terms and conditions applicable to Other Posted Material, as set forth at http:// nrs.harvard.edu/urn-3:HUL.InstRepos:dash.current.terms-of-use\#LAA

\section{Share Your Story}

The Harvard community has made this article openly available.

Please share how this access benefits you. Submit a story.

\section{Accessibility}




\title{
Il Faut Savoir Compter
}

\author{
Robert Darnton
}

I am honored and happy to open this celebration of Daniel Rochel'homme et l'oeuvre, if I may use an antiquated formula from literary history. As to the man, I have known him for thirty-three years and am delighted to pay tribute to a dear friend. The work now fills shelves in libraries throughout the world. It has left an indelible mark on our understanding of history.

Compliments of this kind, however, can sound dangerously like an obituary. Daniel is very much alive, in top form, full of energy, still churning out books, and stirring things up with an inexhaustible stock of ideas and knowledge. I propose, therefore, to concentrate on the oeuvre, especially the early part of it, leaving the later work to the speakers who will follow me.

When I first got to know Daniel in 1970, he quoted the advice he had received from his mentor, Ernest Labrousse: "Pour être historien, il faut savoir compter." At that time, Daniel was preparing his doctoral thesis on the provincial academies. Labrousse had hoped to inspire a Labroussean approach to cultural history-one that would consist of locating a homogeneous run of material in the archives and evaluating it in a way that would reveal the fundamental structures underlying human activity. From histoire sérielle to structures et conjonctures and ultimately histoire totale, the program bore the marks of the Annales school then dominant in France; and I admit I found it horrifying. The quantification of culture! Was not culture a matter of finding meaning in the human condition? Collectively constructed meaning, to be sure, but something that could not be counted like the price of grain? Even when

Robert Darnton is professor of history at Princeton University. His books concern eighteenthcentury France and the history of books and of communication. He served as president of the International Society of Eighteenth-Century Studies from 1987 to 1991 and of the American Historical Association in 1999.

This essay was first delivered as a commentary at the Thirty-first Annual Meeting of the Western Society for French History, held at the University of California, Irvine, in October 2003. 
it was just a glimmer in his eye, Daniel's thesis challenged conventional modes of studying history. It still is a challenge today, a third of a century later.

When it was published, Le siècle des Lumières en province contained, sure enough, a vast amount of quantification: two huge volumes, with 166 pages of statistics, graphs, and maps. ${ }^{1}$ It provided an overview of a vast cultural landscape, the world of provincial academies and the elite who set the tone of intellectual life everywhere outside Paris. Having taught history at a lycée in Châlons-sur-Marne, Daniel appreciated the importance of presenting material clearly, without obfuscating jargon and pretentious discourses on method. He also had developed a healthy appetite for archival research, because the papers of the academy of Châlons were exceptionally rich. They included dozens of treatises submitted to essay contests sponsored by the academy on subjects such as poverty and abuses in criminal law-topics so daring that eventually the foreign minister, the comte de Vergennes, ordered the academy to shift its attention to themes less likely to inflame public opinion. Here then was a body of material that represented Enlightenment thought at a crucial level of diffusion. The Enlightenment itself had been radicalized by the prize essays that Rousseau had submitted to the Academy of Dijon. In the archives of Châlons, Daniel found a run of essays by contemporaries of Rousseau, writers who remained obscure but stirred up a lively debate on public questions in a small provincial city.

The thesis revealed the nature of that debate and of the elite that sponsored it. Daniel had spent fifteen years studying the activities of all thirty-two academies and the social position of their six thousand members. Half of the academicians belonged to the nobility, and their proportion did not decline from the end of the seventeenth century until 1789. Twenty percent came from the clergy, although their role diminished somewhat after 1750 . And the commoners were mainly administrative officials and professional men, especially doctors. They included very few bourgeois in the strict, economic sense of the term: only 3 percent were merchants or manufacturers. The Parisian academies had no one at all from that economic sector. In fact, three-quarters of the members of the Académie Française were noblemen. All the statistics pointed to the same conclusion: the cultural life of France was dominated by a mixed elite, made up in large part of men from the privileged orders.

Daniel never joined the chorus of anti-Marxist history, which was

1 Daniel Roche, Le siècle des Lumières en province: Académies et académiciens provinciaux, 16801789, 2 vols. (Paris, 1978). 
just beginning to be heard in France when he was a graduate student. But more than anyone else he dispatched with the idea of a conquering bourgeoisie and the notion of Enlightenment as bourgeois ideology. He did so despite Labrousse's urging that he identify, statistics in hand, an Enlightenment produced by the bourgeoisie. In his quiet manner, Daniel proved the opposite. His concept of a mixed elite, empowered by new wealth but deeply rooted in the traditional order of societya concept he shared with Jean-Claude Perrot, Maurice Garden, Denis Richet, and even at times Michel Vovelle-opened the way toward a more rigorous sociocultural history. Daniel identified the men who set the tone of provincial society before 1789, who would direct the French Revolution - those whom Timothy Tackett would later portray so effectively in Becoming a Revolutionary-and who would dominate French society throughout the nineteenth century. From the academicians of the Old Regime to the notables of the Third Republic, the trajectory covered a great swath of history and revealed considerable continuity in the midst of change.

It also forced us to reassess the Enlightenment, as I found in my own work on the Encyclopédie. (Having got over my shock at Daniel's quantification, I soon found myself counting books, writers, and readers.) Neither of us accepted Daniel Mornet's model of a diffusion process that worked like a French coffee filter, from the top down, or Arthur Lovejoy's notion of ideas as particles that could be followed from one thinker to another. We wanted to understand how ideas worked themselves into the fabric of society. But when we confronted our results, we wondered whether the Enlightenment, especially in its early stages, had been more of an elitist affair than we had originally imagined. Perhaps Voltaire had understood the sociology of his age when he tried to spread light by working through academies, salons, ministers, and royal mistresses.

The quantitative approach to the Enlightenment continued to look problematic when considered from the perspective of Livre et société, a work that Daniel and other young historians produced, beginning in 1965, under the direction of François Furet. ${ }^{2}$ Instead of beginning in the manner of Mornet by trying to locate the Enlightenment within the literary culture of the Old Regime, the Furet team abandoned preconceptions about Enlightenment and counted books. They compiled statistics from registers of requests for official permission to publish works that were submitted to a censor, and they used categories derived from eighteenth-century libraries. In this way they hoped not only to 
avoid anachronism but also to marry cultural history with histoire sérielle, thereby uncovering the long-term, underlying structure of literary culture. It was an Annales strategy, and it produced Annales results. Tradition outweighed innovation. Works from classical antiquity, orthodox religious literature, jurisprudence, and history outnumbered philosophical tracts and novels. True, belles lettres gained ground at the expense of theology during the course of the century, but the Enlightenment was nowhere to be found. Unfortunately, this difficulty derived from the choice of data and the way of sorting it. The works of the philosophes did not fit easily into the categories used in the classification system, and most of them were excluded from the sources, because they could not pass the censorship in order to qualify for a royal privilège or permission tacite. A few years later, Furet gave up quantification altogether and took the so-called linguistic turn, which led to the study of political ideology and his programmatic version of it in Penser la Révolution française. ${ }^{3}$

Daniel did not take that path. He continued to quantify and to concentrate on social as well as cultural history. Unlike Livre et société, his thesis still stands, twenty-five years after its publication, as a definitive map of the cultural landscape under the Old Regime. But a great deal of "new" history has been written during that quarter century. Few graduate students today have heard of Ernest Labrousse. Few care about counting. Instead, they want to study the cultural construction of gender, the linguistic determinants of high politics, the constitution of the public sphere.... Why compile statistics on cultural phenomena if you understand culture as discourse? Why labor in the archives when you can play language games?

Daniel has answers to those questions, so I will let him speak for himself. But I would like to offer a few observations about his work since 1978. First, it demonstrates a distaste for following what is in vogue. New fashions in history, whether post-Marxist or postmodern, do not appeal to Daniel. Second, it shows an aversion to reductionism. Counting, for Daniel, is a way to make a diagnosis, not to reach a conclusion. He never pretended to explain the intellectual life of academicians by defining their social position. Third, it sometimes seems more Marxist now than it did in 1970. Never having signed on as a Marxist, Daniel did not need to sign off; and he remained sensitive to the importance of class and of economic conflict, while Furet and his followers abandoned social and economic history.

So Daniel never stopped counting, though he shifted his atten-

3 François Furet, Penser la Révolution française (Paris, 1978). 
tion to a wide variety of new subjects-clothes, furniture, water, the ordinary objects that surrounded humble people in their daily lives. As the subject matter changed, so did the perspective. At first, Daniel sought to discover whether the standard of living of Parisian laborers rose or fell during the demographic and economic expansion of the eighteenth century. He found a significant increase in the property of the poor, especially domestic servants, as measured in inventaires après décès, even though some economic indices pointed toward pauperization. The increase showed up especially in wardrobes, a tendency which opened up another study: that of dress and the social codes of clothing. Then, attracted by the work of J. H. Plumb, John Brewer, and other English historians, Daniel tried to see whether the proliferation of better clothes corresponded to a new culture of consumerism. The answer was a qualified yes, with special emphasis on mobility, both social and geographical. That phenomenon led to a study of travel, in fantasy and on foot - but also on horseback, the subject of Daniel's next book.

While the subjects changed, Daniel developed a genre of his own, "l'histoire des choses banales." What holds it together, despite the diversity of the material, is an approach that Daniel calls material anthropology. By reconstructing the environment inhabited by the great majority of Parisians during the seventeenth and eighteenth centuries, he evokes the tenor and the texture of their lives. He describes the fabrics that they wore against their skin, the wood and pewter that they brought to their lips while eating, the intimate warmth generated inside their heavy beds and bedding, the shift in the pressure on their backs as they began to cook on stoves instead of over fireplaces, the new bursts of color that struck their eyes as fashions brightened and the rag-andbone trade boomed. By quantifying thousands of notarial inventories, Daniel and his students avoided the anecdotal, impressionistic subjectivism of the vie quotidienne series. Yet they conveyed the experience of daily life in a world we can barely imagine, one that we may get wrong if we rely too heavily on our imaginations.

Paradoxically, however, Daniel brings this world to life by giving rein to his own, unusually powerful, historical imagination, and "l'imaginaire social" occupies a large place in his account of material culture. How does he get from inventories of objects to the way people construed them in their minds? Not, I believe, by looking for correlations or causes, but rather by consulting the people themselves. Published sources-memoirs, diaries, correspondence, travel books, even novels and sermons - contain so much concrete information accompanied by so many reflections that an imaginative historian can build up 
a picture of the way people invested their surroundings with meaning. Daniel refuses to describe himself as an "historien de mentalités," a term he reserves for Philippe Ariès and Michel Vovelle. But he consistently struggles to make connections between the mental and the material worlds.

He has no formula for accomplishing this feat-nothing beyond total immersion in the archives and in literary sources. If that approach may seem to open the door to impressionism, we should remember that the eighteenth century produced vivid accounts of daily life by writers who lived near the bottom of the social hierarchy-not just LouisSébastien Mercier, Restif de La Bretonne, and Valentin Jamerey-Duval, but also the incomparable Jacques-Louis Ménétra. One of Daniel's greatest achievements was the editing of Ménétra's Journal de ma vie. ${ }^{4}$ He extracted the manuscript from the archives and published it with an introduction that showed how a working man experienced phenomena that appear only as abstractions in standard histories - intergenerational conflict, rites of passage, social mobility, gender relations, ideology, work, space, and time. By writing his autobiography, Ménétra showed how he made sense of the world while making his way through it. And by editing the autobiography, Daniel brought out an element that had remained implicit in his previous work. The Journal de ma vie conveyed l'histoire vécue, lived history in the form of concrete experience infused with thought and affect.

That material anthropology cannot be separated from the life of the mind is apparent to anyone who studies Daniel's footnotes. All the theorists are there: Claude Lévi-Strauss, Roland Barthes, Michel Foucault, Paul Ricoeur, e tutti quanti. Daniel has read his way through all the social thought of twentieth-century France, and he has known many of the thinkers. But he does not parade their names in his texts. And although he uses eclectic mixtures of their ideas when it suits his purpose, he tends to favor some conceptual orientations over others. I may be wrong, but I believe a particular line of thought runs through all his writing. It extends from Emile Durkheim and Marcel Mauss to Pierre Bourdieu, and it expresses a view of cultural practices that characterizes French sociology in general-namely, the conviction that we are born into a world that is already organized by our culture and that we draw on common cultural capital in order to distinguish ourselves from others and to make our way in life. It is the social dimension of thought as well as action, of mentalités as much as choses banales, that intrigues Daniel. He

4 Journal de ma vie: Jacques-Louis Ménétra, compagnon vitrier au $18 e$ siècle, ed. Daniel Roche (Paris, 1982). 
therefore counts, but in counting he takes the pulse of society; he diagnoses the way it feels and thinks as well as the way it dresses and eats. To say that he combines the quantitative and the qualitative approaches to history is too facile. In fact, he is struggling toward the unattainable goal that inspired his masters: l'histoire totale. Now that he has become a master himself, we can be thankful, to l'homme and to l'oeuvre, for showing us the way, even if we shall never get there. 